\title{
SPORTS ANTHROPOLOGICAL COMPARISON OF PHYSICALLY EXERCISING PATIENTS WITH DIABETES TYPE I AND DIABETES TYPE II
}

\author{
Christoph RaschKa, Petra Kothe \\ Institute of Sports Sciences, Julius-Maximilians-University Würzburg, Germany
}

\begin{abstract}
In this study $n=40$ patients with diabetes (type I $n=20$, type II $n=20 ; 20$ males, 20 females), who were regularly practising sports, were examined anthropometrically. Anthropological basic data and computed somatotypical parameters correspond to international standards.

The higher age of athletes with diabetes type II corresponds to the later onset of this form of diabetes.

The registered significant anthropometrical differences between diabetes type I and diabetes type II in both genders correspond to the so-called truncal obesity in the metabolic syndrome and in diabetes type II. The remarkable results support the constitutional importance of the pyknic habitus in diabetes type II in comparison to the pure body fat percentage.
\end{abstract}

\section{INTRODUCTION}

Diabetes mellitus is a group of metabolic disorders, characterized by high blood sugar. The three main types of diabetes are type I diabetes mellitus, resulting from the body's failure to produce insulin due to the destruction of the islet cells in the pancreas, type II diabetes, resulting from insulin resistance and relative insulin deficiency, and gestational diabetes in pregnant women. Diabetes type II makes up about $90 \%$ of cases of diabetes. Globally an estimated 350 million people have type II diabetes. Obesity is thought to be the primary cause of type II diabetes in persons who are genetically predisposed to 
this disease, whereas people with type I diabetes are frequently of slender build. $60-90 \%$ of patients with diabetes type II are obese (HARRISON et al. 2003).

The present study tries to clarify the constitutional and somatotypical differences between physically exercising patients with diabetes type I and II.

\section{PARTICIPANTS AND METHODS}

In this study $n=20$ patients with diabetes type I ( 10 males, 10 females; $70 \%$ of them practising an endurance sports, $30 \%$ ball games) who did work outs for 3 to 4 times per week, duration ca. $60-90$ min per session) and $\mathrm{n}=20$ persons with diabetes type II (10 males, 10 females, $90 \%$ of them participating in general gymnastics sessions 1-2 times per week, duration ca. 60 min per session) were examined. Each proband participated voluntarily and the data were used anonymously.

Anthropometric data and computed constitutional and somatotypical parameters in this work correspond to international standards (Conrad 1963, Heath\&Carter 1967+1990, Knussmann 1996, Martin\&Knussmann 1988, Raschka 2006, Tittel\&Wutscherk 1972). The analysis of differences was tested by ANOVA.

\section{RESULTS}

The results are summarized in Table 1 and in Figures 1-4.

Table 1. Averages, standard deviations and significance levels of selected parameters for both genders and Diabetes Type I v.s Diabetes Type II

\begin{tabular}{lccccc}
\hline Parameter & $\begin{array}{c}\hat{0} \\
\text { Diabetes I }\end{array}$ & $\begin{array}{c}q \\
\text { Diabetes I }\end{array}$ & $\begin{array}{c}\hat{0} \\
\text { Diabetes II }\end{array}$ & $\begin{array}{c}q \\
\text { Diabetes II }\end{array}$ & $P$ \\
\hline Age (years) & $39.8 \pm 10.0$ & $41.0 \pm 17.7$ & $68.3 \pm 4.7$ & $65.4 \pm 8.6$ & $<0.001$ \\
\hline Height $(\mathrm{cm})$ & $182.0 \pm 5.2$ & $170.3 \pm 8.1$ & $176.7 \pm 8.6$ & $163.3 \pm 7.1$ & $<0.05$ \\
\hline Forearm length $(\mathrm{cm})$ & $26.2 \pm 2.5$ & $22.9 \pm 2.8$ & $25.1 \pm 2.3$ & $23.5 \pm 1.6$ & n.s. \\
\hline $\begin{array}{l}\text { Morphological facial height } \\
\text { (cm) }\end{array}$ & $12.2 \pm 1.6$ & $11.0 \pm 0.9$ & $12.8 \pm 0.6$ & $11.9 \pm 0.7$ & $<0.05$ \\
\hline Neck length $(\mathrm{cm})$ & $11.6 \pm 2.0$ & $10.1 \pm 1.6$ & $9.0 \pm 1.5$ & $8.4 \pm 1.5$ & $<0.001$ \\
\hline Neck circumference $(\mathrm{cm})$ & $39.0 \pm 2.4$ & $32.8 \pm 1.5$ & $42.6 \pm 6.3$ & $37.3 \pm 2.1$ & $<0.01$ \\
\hline Chest circumference $(\mathrm{cm})$ & $97.8 \pm 10.7$ & $78.2 \pm 4.6$ & $107.4 \pm 9.8$ & $101.3 \pm 10.9$ & $<0.001$ \\
\hline Waist circumference $(\mathrm{cm})$ & $95.0 \pm 12.0$ & $78.9 \pm 9.2$ & $109.9 \pm 15.3$ & $106.2 \pm 14.9$ & $<0.001$ \\
\hline
\end{tabular}


Table 1. Continuation

\begin{tabular}{|c|c|c|c|c|c|}
\hline Parameter & $\begin{array}{c}\sigma^{\pi} \\
\text { Diabetes I }\end{array}$ & $\begin{array}{c}\text { 우 } \\
\text { Diabetes I }\end{array}$ & Diabetes II & $\begin{array}{c}\text { 우 } \\
\text { Diabetes II }\end{array}$ & $\mathrm{P}$ \\
\hline Hip circumference $(\mathrm{cm})$ & $101.7 \pm 9.6$ & $96.1 \pm 6.4$ & $111.3 \pm 15.3$ & $113.9 \pm 11.8$ & $<0.001$ \\
\hline Biceps circumference $(\mathrm{cm})$ & $32.4 \pm 2.9$ & $27.9 \pm 1.6$ & $32.6 \pm 4.1$ & $32.2 \pm 3.4$ & $<0.05$ \\
\hline Forearm circumference $(\mathrm{cm})$ & $28.0 \pm 1.8$ & $24.3 \pm 1.1$ & $28.3 \pm 1.9$ & $25.9 \pm 1.7$ & n.s. \\
\hline Hand circumference $(\mathrm{cm})$ & $22.2 \pm 1.3$ & $18.9 \pm 1.2$ & $21.4 \pm 3.9$ & $19.6 \pm 1.1$ & n.s. \\
\hline Calf circumference (cm) & $40.5 \pm 2.1$ & $36.7 \pm 2.5$ & $38.8 \pm 4.0$ & $36.7 \pm 3.5$ & n.s. \\
\hline Triceps skinfold (mm) & $16.6 \pm 5.1$ & $24.1 \pm 5.1$ & $18.6 \pm 8.7$ & $22.9 \pm 6.9$ & n.s. \\
\hline Forearm skinfold (mm) & $13.3 \pm 8.0$ & $12.3 \pm 3.5$ & $12.9 \pm 6.6$ & $15.4 \pm 6.2$ & n.s. \\
\hline Subscapular skinfold (mm) & $18.9 \pm 5.9$ & $17.3 \pm 3.6$ & $20.6 \pm 7.1$ & $25.0 \pm 5.6$ & $<0.05$ \\
\hline Suprailiacal skinfold (mm) & $10.9 \pm 4.3$ & $15.5 \pm 2.9$ & $10.2 \pm 3.7$ & $12.8 \pm 3.8$ & n.s. \\
\hline Calf skinfold (mm) & $25.5 \pm 8.8$ & $25.0 \pm 5.5$ & $20.1 \pm 9.7$ & $23.0 \pm 8.3$ & n.s. \\
\hline Shoulder width $(\mathrm{cm})$ & $39.3 \pm 2.6$ & $33.0 \pm 2.0$ & $39.9 \pm 1.3$ & $36.8 \pm 1.1$ & $<0.001$ \\
\hline Chest width $(\mathrm{cm})$ & $30.6 \pm 3.2$ & $23.8 \pm 5.9$ & $33.0 \pm 2.1$ & $30.4 \pm 1.6$ & $<0.001$ \\
\hline Chest depth (cm) & $23.1 \pm 4.1$ & $19.3 \pm 2.4$ & $27.2 \pm 2.8$ & $27.2 \pm 3.3$ & $<0.001$ \\
\hline Zygomatic width (cm) & $13.7 \pm 1.8$ & $12.2 \pm 0.4$ & $13.8 \pm 0.4$ & $12.8 \pm 1.6$ & n.s. \\
\hline $\begin{array}{l}\text { Epiphysis width humerus } \\
\text { (cm) }\end{array}$ & $9.1 \pm 1.7$ & $7.1 \pm 0.4$ & $8.5 \pm 0.7$ & $8.0 \pm 1.1$ & n.s. \\
\hline Epiphysis width femur (cm) & $10.6 \pm 1.3$ & $8.8 \pm 0.6$ & $10.3 \pm 0.9$ & $9.7 \pm 0.9$ & n.s. \\
\hline $\left.\operatorname{BMI}\left(\mathrm{kg} / \mathrm{m}^{2}\right)\right)$ & $25.1 \pm 2.9$ & $21.6 \pm 1.7$ & $27.9 \pm 5.1$ & $29.1 \pm 5.0$ & $<0.001$ \\
\hline Lean body mass $(\mathrm{kg})$ & $70.7 \pm 9.7$ & $47.6 \pm 6.2$ & $72.6 \pm 13.7$ & $59.8 \pm 8.7$ & $<0.05$ \\
\hline Waist-to-hip-ratio & $0.95 \pm 0.1$ & $0.83 \pm 0.1$ & $0.99 \pm 0.1$ & $0.93 \pm 0.1$ & $<0.01$ \\
\hline Rohrer Index $\left(\mathrm{g}^{*} 100 / \mathrm{cm}^{3}\right)$ & $1.4 \pm 0.1$ & $1.3 \pm 0.1$ & $1.5 \pm 0.2$ & $1.8 \pm 0.3$ & $<0.001$ \\
\hline Relative chest width (\%) & $16.8 \pm 1.5$ & $14.6 \pm 1.8$ & $18.7 \pm 1.1$ & $18.6 \pm 1.2$ & $<0.001$ \\
\hline Neck index (\%) & $29.8 \pm 4.2$ & $31.0 \pm 6.1$ & $21.8 \pm 4.3$ & $22.8 \pm 4.9$ & $<0.001$ \\
\hline $\begin{array}{l}\text { Forearm length- } \\
\text { circumference index (\%) }\end{array}$ & $107.6 \pm 11.4$ & $97.0 \pm 32.7$ & $122.4 \pm 28.3$ & $110.9 \pm 12.7$ & n.s. \\
\hline $\begin{array}{l}\text { Forearm fat/circumference } \\
\text { index }(\%)\end{array}$ & $4.7 \pm 2.9$ & $5.1 \pm 1.4$ & $4.5 \pm 2.1$ & $5.6 \pm 1.9$ & n.s. \\
\hline Morphological facial index & $89.7 \pm 6.4$ & $90.6 \pm 7.0$ & $92.9 \pm 5.4$ & $94.7 \pm 16.1$ & n.s. \\
\hline Endomorphy (after Parnell) & $4.1 \pm 0.5$ & $4.7 \pm 0.5$ & $4.0 \pm 0.7$ & $4.5 \pm 0.4$ & n.s. \\
\hline Mesomorphy (after Parnell) & $4.6 \pm 0.7$ & $3.2 \pm 0.9$ & $5.0 \pm 1.0$ & $5.7 \pm 1.6$ & $<0.001$ \\
\hline Ectomorphy (after Parnell) & $3.8 \pm 0.8$ & $4.1 \pm 1.0$ & $2.8 \pm 1.2$ & $2.1 \pm 1.0$ & $<0.001$ \\
\hline $\begin{array}{l}\text { Endomorphy (after Heath / } \\
\text { Carter) }\end{array}$ & $4.4 \pm 0.9$ & $5.6 \pm 0.7$ & $4.7 \pm 1.4$ & $6.0 \pm 0.9$ & n.s. \\
\hline $\begin{array}{l}\text { Mesomorphy (after } \\
\text { Heath/Carter) }\end{array}$ & $6.5 \pm 1.8$ & $3.8 \pm 0.8$ & $6.4 \pm 1.6$ & $7.0 \pm 2.2$ & $<0.01$ \\
\hline
\end{tabular}


Table 1. Continuation

\begin{tabular}{|c|c|c|c|c|c|}
\hline Parameter & $\begin{array}{c}\text { वृ } \\
\text { Diabetes I }\end{array}$ & $\begin{array}{c}\text { 우 } \\
\text { Diabetes I }\end{array}$ & $\begin{array}{c}\sigma^{\top} \\
\text { Diabetes II }\end{array}$ & $\begin{array}{c}\text { 우 } \\
\text { Diabetes II }\end{array}$ & $\mathrm{P}$ \\
\hline $\begin{array}{l}\text { Ectomorphy (after } \\
\text { Heath(Carter) }\end{array}$ & $2.1 \pm 1.0$ & $2.7 \pm 1.0$ & $1.2 \pm 1.0$ & $0.7 \pm 0.7$ & $<0.001$ \\
\hline Metrik-Index (after Conrad) & $-0.2 \pm 1.0$ & $-1.0 \pm 0.7$ & $0.9 \pm 0.6$ & $1.4 \pm 0.9$ & $<0.001$ \\
\hline Plastik-Index (after Conrad) & $89.5 \pm 5.3$ & $76.2 \pm 3.6$ & $90.6 \pm 3.2$ & $82.2 \pm 3.1$ & $<0.01$ \\
\hline $\begin{array}{l}\text { Macrosomia (after } \\
\text { Knussmann) }\end{array}$ & $5.2 \pm 2.1$ & $3.8 \pm 2.2$ & $5.3 \pm 1.6$ & $4.6 \pm 1.4$ & n.s. \\
\hline $\begin{array}{l}\text { Pyknomorphy (after } \\
\text { Knussmann) }\end{array}$ & $-0.5 \pm 2.5$ & $-2.8 \pm 2.0$ & $-1.4 \pm 3.4$ & $-1.7 \pm 2.9$ & n.s. \\
\hline 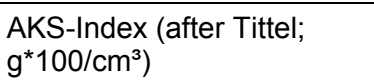 & $1.2 \pm 0.1$ & $1.0 \pm 0.1$ & $1.3 \pm 0.2$ & $1.4 \pm 0.2$ & $<0.001$ \\
\hline
\end{tabular}

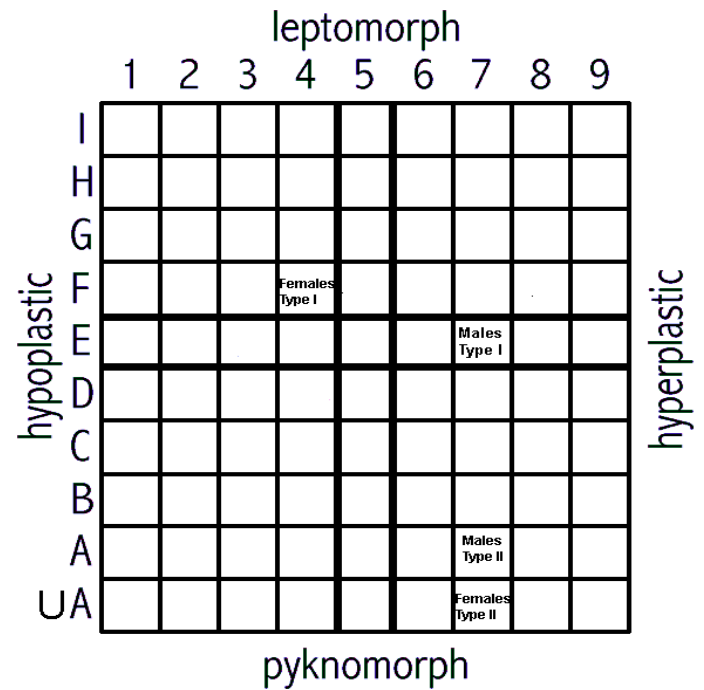

Figure 1. Average constitutional types of male and female athletes with Diabetes Type I and II in the chessboard pattern diagram after Conrad 


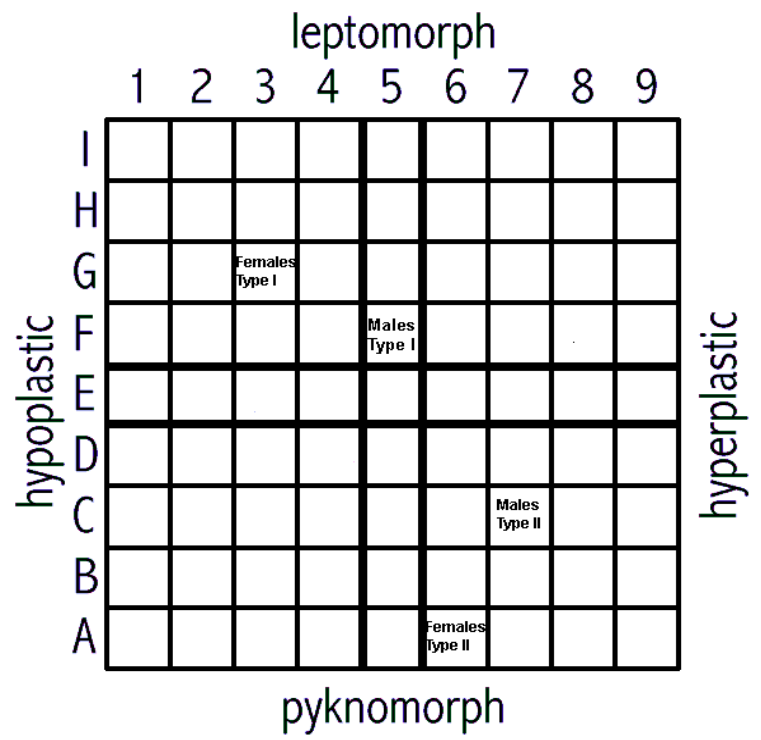

Figure 2. Average constitutional types of male and female athletes with Diabetes Type I and II in the chessboard pattern diagram after Conrad after the application of a correction factor for age

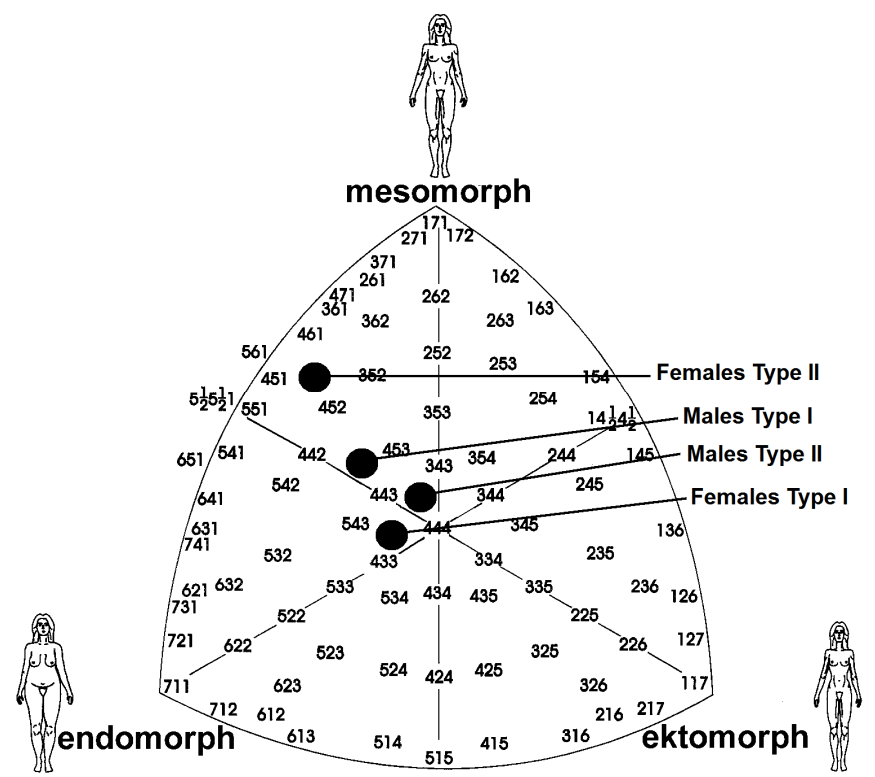

Figure 3. Average somatotypes of male and female athletes with Diabetes Type I and II in the somatochart after Parnell 


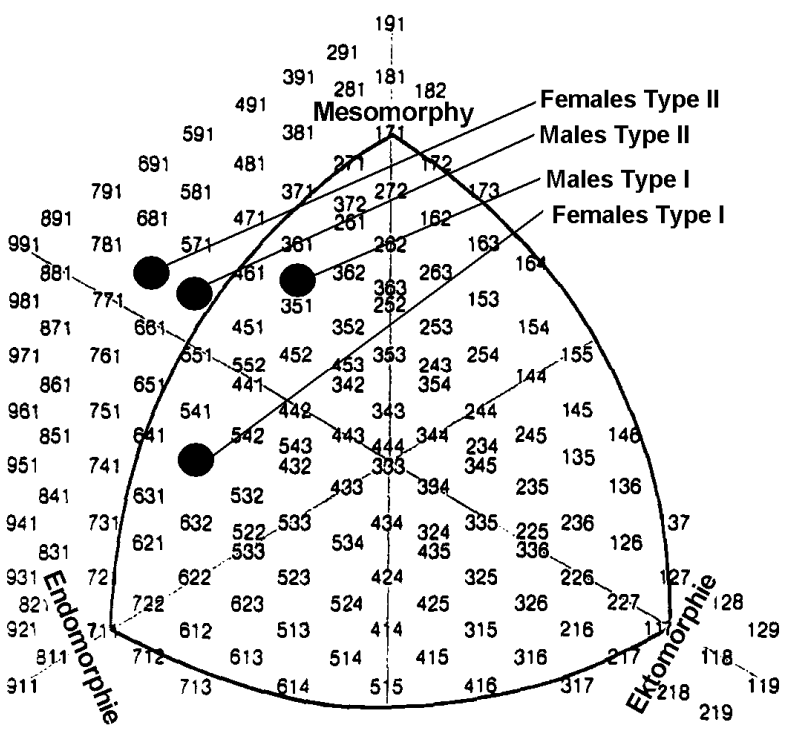

Figure 4. Average somatotypes of male and female athletes with Diabetes Type I and II in the somatochart after Heath \& Carter

\section{DISCUSSION}

The higher age of athletes with diabetes type II is not surprising. Classically the onset of diabetes mellitus Type II (non-insulin-dependent diabetes mellitus = NIDDM, former category of adult(maturity)-onset of stable diabetes mellitus) is after the age of 40 years; however, this type of diabetes may be diagnosed at any age (Harrison et al. 2003).

The registered significant anthropometrical differences between diabetes type I and II in both genders underline the importance of the so-called truncal obesity in the so-called metabolic syndrome and in the development of diabetes type II. The metabolic syndrome, which is also known as syndrome $\mathrm{X}$, is a combination of medical disorders, that, when occurring together, increase the risk of developing diabetes and the cardiovascular disease. The prevalence in the USA is an estimated $25 \%$ of the population, increasing with age (Harrison et al. 2003).

When using and interpreting the significant parameters in this study one might imagine the well known picture of the leptomorph type after Kretschmer (1921), Conrad (1963) and Knussmann (1996) for the diabetes type II compared to diabetes type I: 
Shorter length of neck ("buffalo neck"), smaller figure, compacter form, higher circumferences of neck, chest, waist, hip, upper arm, higher BMI and Rohrer-indices, broader shoulders and chest dimensions (width, depth) thus representing truncal obesity, whereas the differences of other circumferences of the extremities and of the skinfolds (with the exception of the subscapular skinfold, which represents mainly the fat content of the upper trunk) were not significant. The results support the constitutional importance of the pyknic habitus.

For significant differences less the general development of subcutaneous adipose tissue, rather than the development of the regional body dimensions of the trunk towards a pyknomorph habitus seems to play the decisive role. This finding of this explorative study is remarkable.

In line with the reduced importance of the pure fat component differences (skinfolds) between the two types of diabetes mellitus are also the missing significances for the endomorphy in body somatotyping techniques after Parnell (1954) and Heath \& Carter (1967), because this methodology is based on the determination of pure skinfolds. Instead, significant differences arise primarily for the ectomorphy after Parnell (1954) and Heath \& Carter (1967), which is based purely on the body size and the weight by means of the height weight - ratio (ponderal index). This is similar for the mesomorphy, which is calculated of corrected circumferences and the height.

As expected the results were also significant for the indices after Conrad (1963) and Tittel \& Wutscherk (1972).

From an anthropological point of view these anthropometrical findings deserve further critical examination in clinical follow-up studies.

\section{REFERENCES}

1. Harrison T. R., Braunwald E., Dietel M. [Eds.] (2003). Harrison's principles of internal medicine. 15. Aufl. London, McGraw-Hill.

2. Conrad K. (1963). Der Konstitutionstypus. Berlin: Springer Verlag.

3. Heath B. H. Carter L. J. E. (1967). A modified somatotype method. Am J Phys Anthrop, 27, 57-74.

4. Heath B. H. Carter L. J. E. (1990). Somatotyping- development and applications. Cambridge Studies in Biological Anthropology. Great Britain: Redwood Press.

5. Knußmann R. (1996). Vergleichende Biologie des Menschen. Lehrbuch der Anthropologie. Stuttgart, Gustav Fischer Verlag.

6. Kretschmer E. (1921). Körperbau und Charakter. Berlin, Springer Verlag. 
7. Martin R., Knussmann R. (1988). Anthropologie. Handbuch. Band I. Stuttgart, Fischer Verlag

8. Parnell R.W. (1954). Somatotyping by physical anthropometry. Am J Phys Anthrop, 12, 209-210.

9. Raschka C. (2006). Sportanthropologie, Köln, Sportverlag Strauß.

10. Tittel K., Wutscherk H. (1972). Sportanthropometrie, Leipzig, Barth.

\section{Adress for correspondence}

Priv.-Doz. Dr.med. Dr.rer.nat. Dr.Sportwiss. Christoph Raschka

Institute of Sports Sciences

Julius-Maximilians-University

Judenbühlweg 11, D-97082 Würzburg, Germany

E-mail: christoph.raschka@uni-wuerzburg.de 